\title{
Corrected Values for Boiling Points and Enthalpies of Vaporization of Elements in Handbooks
}

\author{
Yiming Zhang
}

Ningbo Institute of Material Technology \& Engineering, Chinese Academy of Sciences, No. 519 Zhuangshi Road, Zhenhai District, Ningbo, Zhejiang Province, P.R. China 315201, and Department of Materials, Queen Mary University of London, Mile End Road, London E1 4NS, United Kingdom

Julian R. G. Evans

Department of Chemistry, University College London, 20 Gordon Street, London WC1H 0AJ, United Kingdom

\author{
Shoufeng Yang*
}

School of Engineering Sciences, University of Southampton, Southampton, SO17 1BJ, United Kingdom

\begin{abstract}
The scientific community relies upon the veracity of the scientific data in handbooks and databases. In a previous work, the authors developed a systematic, intelligent, and potentially automatic method to detect errors in such resources based on artificial neural networks (ANNs). This method revealed variations from (10 to 900 ) \% in tables of property data for elements in the periodic table and pointed out the ones that are most probably correct. In this paper, we focus on the details of employing this method for analyzing the data of boiling points and enthalpies of vaporization recorded in different handbooks. The method points out the values that are likely to be correct. To verify the method employed, a detailed discussion of the data with reference to the original literature sources is given as well as factors that may affect the accuracy of the prediction.
\end{abstract}

\section{Introduction}

It is well-known that both the boiling point and the enthalpy of vaporization are important thermodynamic properties that are required in product design and processes involving liquid and vapor phase transitions such as distillation, vaporization, and drying $^{1-3}$ and that, as a result, the quality and veracity of these data in handbooks are important for the academic and industrial scientific community. ${ }^{4}$ However, it is accepted that errors in handbooks and databases are inescapable and are anticipated at rates of (1 to 5$) \% .^{5-7}$

This work challenges the inevitability of such high error rates. The values of boiling point and enthalpy of vaporization of the elements were recorded for testing, because these data are expected to be very reliable; only the elements with short halflives were excluded. Tables 1 and 2 show the boiling point and enthalpy of vaporization values of elements in the periodic table taken from five different handbooks. Considerable variation in the values can be noticed, so it can be concluded that inconsistencies are extant within these handbooks, and these inconsistencies have persisted undetected into the 21 st century.

In the authors' related work, ${ }^{8}$ we developed a systematic and intelligent method based on artificial neural networks (ANNs) to detect wide levels of inconsistencies in handbooks and so stop their transmission to future researches and documents. In this paper, we are going to show the details of application of this method in the case of correcting values of the boiling point and enthalpy of vaporization for the elements.

* Authors to whom correspondence should be addressed. E-mail: s.yang@ soton.ac.uk. Tel.: 0044-23-8059-8697. Fax: 0044-23 80593016.

\section{Experimental Details}

Data Collection and Neural Network Construction. The data are recorded from five different handbooks, including the Chemistry Data Book (CDB), ${ }^{9}$ The Lange's Handbook of Chemistry (LAG), ${ }^{10}$ The Elements (ELE), ${ }^{11}$ Table of Physical and Chemical Constants (TPC), ${ }^{12}$ and CRC Handbook of Chemistry and Physics (CRC). ${ }^{13}$ The neural networks are constructed, trained, and simulated by employing MATLAB 7.4.0.287 (R2007a) software. A two-hidden layer network with tan-sigmoid transfer function in the first hidden layer and a linear transfer function in the second hidden layer was established. A loop program was applied to redistribute the database to make the training set cover the problem domain. ${ }^{14,15}$ The detailed process of data collection and neural network construction has been described in the authors' related works. ${ }^{8}$ The ANN finds indirect relationships between data sets and then identifies values which disobey the relationship.

Stages of Error Correction. This includes four different stages.

Stage 1. During the exploration of the indirect relationship between boiling point and enthalpy of vaporization using data from CDB (shown in Table 3) by an ANN, best linear fit equations with a regression coefficient of $R=0.973$ and 0.972 were found (as shown in Figure 1). This result prompts us to raise the correlation hypothesis that the correlation applies to all of the elements.

Stage 2. In this stage, a conformity criterion is selected. On the basis of the inconsistency within different handbooks, 
Table 1. List of Boiling Points Divided by Kelvin from Five Handbooks ${ }^{a}$

\begin{tabular}{|c|c|c|c|c|c|c|}
\hline element & $\mathrm{CDB}$ & $\mathrm{LAG}^{b}$ & ELE & TPC & $\mathrm{CRC}$ & $(\max / \min -1) \cdot 100 \%$ \\
\hline $\mathrm{Ag}^{c}$ & 2483 & 2483 & 2485 & 2433 & 2435 & $2.14 \%$ \\
\hline $\mathrm{Al}^{c}$ & 2743 & 2743 & 2740 & 2793 & 2792 & $1.93 \%$ \\
\hline $\mathrm{Ar}$ & 87.15 & 87.15 & 87.29 & 87.29 & 87.3 & $0.17 \%$ \\
\hline $\mathrm{Au}$ & 3243 & 3243 & 3080 & 3123 & 3129 & $5.29 \%$ \\
\hline $\mathrm{Ba}^{e}$ & 1913 & 1913 & 1910 & 2173 & 2170 & $13.80 \%$ \\
\hline $\mathrm{Be}^{e}$ & 2750 & 2750 & $3243^{f}$ & 2743 & 2744 & $18.20 \%$ \\
\hline $\mathrm{B}^{c}$ & 4203 & 4203 & 3931 & 4273 & 4273 & $8.70 \%$ \\
\hline $\mathrm{C}\left(\right.$ graphite $^{e}$ & 5103 & 5103 & $5100^{d}$ & - & $4098^{d}$ & $24.50 \%$ \\
\hline $\mathrm{Ca}$ & 1760 & 1760 & 1757 & 1757 & 1757 & $0.17 \%$ \\
\hline $\mathrm{Cd}$ & 1038 & 1038 & 1038 & 1043 & 1040 & $0.48 \%$ \\
\hline $\mathrm{Ce}^{c}$ & 3743 & 3743 & 3699 & 3693 & 3716 & $1.35 \%$ \\
\hline $\mathrm{Cl}$ & 238.5 & 238.5 & 239.2 & 239.2 & 239.1 & $0.29 \%$ \\
\hline Co & 3173 & 3173 & 3143 & 3203 & 3200 & $1.91 \%$ \\
\hline $\mathrm{Eu}$ & 1713 & 1713 & 1870 & 1873 & 1802 & $9.34 \%$ \\
\hline $\mathrm{F}$ & 85.15 & 85.15 & 85.01 & 85.05 & 85.03 & $0.16 \%$ \\
\hline $\mathrm{Fe}$ & 3273 & 3273 & 3023 & 3133 & 3134 & $8.27 \%$ \\
\hline $\mathrm{Ga}$ & 2673 & 2673 & 2676 & 2473 & 2477 & $8.21 \%$ \\
\hline $\mathrm{Gd}$ & 3273 & 3273 & 3539 & 3533 & 3546 & $8.34 \%$ \\
\hline $\mathrm{Ge}$ & 3103 & 3103 & 3103 & 3103 & 3106 & $0.10 \%$ \\
\hline $\mathrm{H}$ & 21.15 & 21.15 & 20.28 & 20.28 & 20.28 & $4.29 \%$ \\
\hline $\mathrm{He}$ & 4.15 & 4.15 & 4.216 & 4.37 & 4.22 & $5.30 \%$ \\
\hline $\mathrm{Hf}^{g}$ & 5673 & 5673 & 5470 & 4873 & 4876 & $16.40 \%$ \\
\hline $\mathrm{Hg}$ & 630.2 & 630.2 & 629.7 & 629.8 & 629.9 & $0.08 \%$ \\
\hline $\mathrm{Ho}^{c}$ & 2873 & 2873 & 2968 & 2973 & 2973 & $3.48 \%$ \\
\hline $\mathrm{I}\left(\mathrm{I}_{2}\right)^{c}$ & 457.2 & 457.2 & 457.5 & 457.2 & 457.6 & $0.09 \%$ \\
\hline In & 2273 & 2273 & 2353 & 2343 & 2345 & $3.52 \%$ \\
\hline $\mathrm{Ir}^{g}$ & 5573 & 5573 & 4403 & 4703 & 4701 & $26.60 \%$ \\
\hline $\mathrm{N}$ & 77.15 & 77.15 & 77.4 & 77.35 & 77.36 & $0.32 \%$ \\
\hline $\mathrm{Na}^{c}$ & 1163 & 1163 & 1156 & 1153 & 1156 & $0.87 \%$ \\
\hline $\mathrm{Nb}^{e}$ & 3573 & 3573 & 5015 & 4973 & 5017 & $40.40 \%$ \\
\hline $\mathrm{Nd}$ & 3303 & 3303 & 3341 & 3343 & 3347 & $1.33 \%$ \\
\hline $\mathrm{Ne}$ & 27.15 & 27.15 & 27.1 & 27.07 & 27.07 & $0.30 \%$ \\
\hline $\mathrm{Ni}^{b}$ & 3003 & 3003 & 3005 & 3263 & 3186 & $8.66 \%$ \\
\hline $\mathrm{O}$ & 90.15 & 90.15 & 90.19 & 90.19 & 90.2 & $0.06 \%$ \\
\hline $\mathrm{Os}^{c}$ & 5273 & 5273 & 5300 & 5273 & 5285 & $0.51 \%$ \\
\hline $\mathrm{P}(\text { white })^{c}$ & 553.2 & 553.2 & 553 & 550.2 & 553.7 & $0.64 \%$ \\
\hline $\mathrm{Pb}$ & 2017 & 2017 & 2013 & 2023 & 2022 & $0.50 \%$ \\
\hline $\mathrm{Pd}^{e}$ & 4253 & 4253 & 3413 & 3233 & 3236 & $31.60 \%$ \\
\hline $\operatorname{Pr}^{e}$ & 3403 & 3403 & 3785 & 3783 & 3793 & $11.50 \%$ \\
\hline $\mathrm{Pt}^{b, h}$ & 4803 & 4803 & 4100 & 4093 & 4098 & $17.40 \%$ \\
\hline $\mathrm{Rb}$ & 961.2 & 961.2 & 961 & 963.2 & 961.2 & $0.23 \%$ \\
\hline $\operatorname{Re}^{c}$ & 5903 & 5903 & 5900 & 5873 & 5869 & $0.58 \%$ \\
\hline $\mathrm{Rh}^{e}$ & 4773 & 4773 & 4000 & 3973 & 3968 & $20.30 \%$ \\
\hline $\mathrm{Ru}^{h}$ & 5173 & 5173 & 4173 & 4423 & 4423 & $24.00 \%$ \\
\hline $\mathrm{S}(\text { monoclinic })^{c}$ & 718.2 & 718.2 & 717.8 & 717.8 & 717.8 & $0.06 \%$ \\
\hline $\mathrm{Sb}^{g}$ & 1653 & 1653 & 1908 & 1860 & 1860 & $15.40 \%$ \\
\hline $\mathrm{Sc}$ & 3003 & 3003 & 3104 & 3103 & 3109 & $3.53 \%$ \\
\hline $\mathrm{Se}^{c}$ & 958.2 & 958.2 & 958.1 & 958.2 & 958.2 & $0.01 \%$ \\
\hline $\mathrm{Si}^{g}$ & 2633 & 2633 & 2628 & 3533 & 3538 & $34.60 \%$ \\
\hline $\mathrm{Sm}^{c}$ & 2173 & 2173 & 2064 & 2063 & 2067 & $5.33 \%$ \\
\hline $\mathrm{Sn}^{e}$ & 2543 & 2543 & 2543 & 2893 & 2875 & $13.80 \%$ \\
\hline $\mathrm{Sr}$ & 1653 & 1653 & 1657 & 1653 & 1655 & $0.24 \%$ \\
\hline $\mathrm{Ta}$ & 5693 & 5693 & 5698 & 5833 & 5731 & $2.46 \%$ \\
\hline $\mathrm{Tb}^{g}$ & 3073 & 3073 & 3396 & 3493 & 3503 & $14.00 \%$ \\
\hline $\mathrm{Te}^{c}$ & 1263 & 1263 & 1263 & 1263 & 1261 & $0.16 \%$ \\
\hline
\end{tabular}


Table 1. Continued

\begin{tabular}{|c|c|c|c|c|c|c|}
\hline element & $\mathrm{CDB}$ & $\mathrm{LAG}^{b}$ & ELE & TPC & CRC & $(\max / \min -1) \cdot 100 \%$ \\
\hline $\mathrm{Xe}$ & 165.2 & 165.2 & 166.1 & 165.1 & 165 & $0.67 \%$ \\
\hline $\mathrm{Yb}^{e}$ & 1703 & 1703 & 1466 & 1473 & 1469 & $16.20 \%$ \\
\hline $\mathrm{Y}^{e}$ & 3203 & 3203 & 3611 & 3613 & 3618 & $13.00 \%$ \\
\hline $\mathrm{Zn}$ & 1180 & 1180 & 1180 & 1183 & 1180 & $0.25 \%$ \\
\hline $\mathrm{Zr}^{g}$ & 3853 & 3853 & 4650 & 4673 & 4682 & $21.50 \%$ \\
\hline
\end{tabular}

${ }^{a}$ Acronyms as in text. This table does not have exclusions based on judgement. The elements are in alphabetical order. ${ }^{b}$ The boiling point is different in different tables of LAG. For example, nickel (Ni) is $2884{ }^{\circ} \mathrm{C}$ in page 1.43 (Table 1.3) and $2730{ }^{\circ} \mathrm{C}$ in page 1.125 (Table 1.19 ). We selected most of the boiling points from the later table. ${ }^{c}$ Category I: the data of the boiling point for these elements are consistent in different handbooks, but those of the enthalpy of vaporization are not. ${ }^{d}$ Sublimation. ${ }^{e}$ Category II: the data of the enthalpy of vaporization for these elements are consistent in different handbooks, but those of the boiling point are not. ${ }^{f}$ Under pressure. ${ }^{g}$ Category III: the data of neither the boiling point nor the enthalpy of vaporization for these elements are consistent in different handbooks. ${ }^{h}$ The variation of boiling points of Pt and Ru are greater than $10 \%$, but here due to shortage of data in range of ( 3603.15 to 5693.15$) \mathrm{K}$ in category IV, they were classified into category IV by identifying the closest value from the literature to reduce the uncertainty in that range. ${ }^{30,31}$

elements were then classified into four different categories based on a $10 \%$ variation between minimum and maximum values:

I. Boiling points of the elements are consistent, but enthalpies of vaporization are inconsistent (shown in Table 4).

II. Enthalpies of vaporization are consistent, but boiling points are inconsistent (shown in Table 5).

III. Both boiling points and enthalpies of vaporization are inconsistent (shown in Table 6).

IV. Both boiling points and enthalpies of vaporization are consistent (shown in Table 7).

Stage 3. We then use the data belonging to category IV to train a second set of ANNs: ANN1 and ANN2. ANN1 is used to predict enthalpies of vaporization from boiling points, while ANN2 is used to predict boiling points from enthalpies of vaporization. Here, ANN1 and ANN2 discover and capture an indirect correlation between just two properties from category IV data set, but this method can be applied in any situation when the correlations between several properties can be captured by ANNs. ${ }^{8}$ We now suppose these two ANNs to have been trained on "consistent" data providing a robust correlation against which the consistency of other data can be judged. The details of construction for these two ANNs can be found in the authors' related work. ${ }^{8}$

Stage 4. Consistent values are now used to identify inconsistent data. At first, the ANN1 was used to predict enthalpies of vaporization of elements in category I using the consistent boiling points; then the outputs are compared with the handbook data to isolate suspect data for the enthalpy of vaporization. For example, Al has consistent boiling point values from (2740 to 2793$) \mathrm{K}$ (1.9\% difference) in all of the handbooks consulted, but enthalpies of vaporization vary from (29 to 294$) \mathrm{kJ} \cdot \mathrm{mol}^{-1}$ (910\% difference). The ANN-predicted enthalpy of vaporization is $281 \mathrm{~kJ} \cdot \mathrm{mol}^{-1}$, which is close to one handbook value, 284 $\mathrm{kJ} \cdot \mathrm{mol}^{-1}(\mathrm{CDB})$. The difference between the predicted and the closest literature value is now $1.2 \%$.

The second part of stage 4 is to use the consistent enthalpies of vaporization as input values in ANN2 to predict boiling points of elements in category II for isolating suspect boiling point data.

In the third part of stage 4 , for the data in category III, a method to calculate a comprehensive minimum of difference was constructed. ${ }^{8}$

\section{Results and Discussion}

In the first part of stage 4, the ANN1 is able to point out the correct enthalpies of vaporization from the inconsistent values from different handbooks. Most of the differences (11 out of 16, including $\mathrm{Na}, \mathrm{Al}, \mathrm{B}, \mathrm{Os}, \mathrm{Kr}, \mathrm{Ag}, \mathrm{Te}, \mathrm{Bi}, \mathrm{Re}, \mathrm{Ce}$, and $\mathrm{Sm}$ ) between the predicted and the closest recorded values of enthalpy of vaporization are now less than $10 \%$. The results of this stage are listed in Table 8 . The average error for enthalpy of vaporization in category I decreased from $231 \%$ (Table 4) to $8.8 \%$ (Table 8 ). Inconsistencies for another five elements (I, P (white), Se, Ho, S) have decreased dramatically as well but are still slightly greater than $10 \%$. That could be because none of the data in the handbooks was correct but that the ANN gave a correct estimate. Those five elements will be discussed later.

In the second part of stage 4, in a similar way, ANN2 is able to point out the correct boiling point from inconsistent values. Predicted and closest recorded values of boiling points for most of the samples now differ by less than $10 \%$ (10 out of 12 elements, including $\mathrm{Pd}, \mathrm{Nb}, \mathrm{Yb}, \mathrm{Rh}, \mathrm{Y}, \mathrm{C}$ (graphite), Be, Sn, $\mathrm{V}, \mathrm{Pr}$ ), as shown in Table 9. The average error of the boiling point in category II decreased from $18.9 \%$ (Table 5) to $6.4 \%$ (Table 9). Deviations of another two elements (Ba, Tm) have decreased as well but are still higher than $10 \%$, and these will be discussed later.

In the last part of stage 4, both ANN1 and ANN2 are used to point out the correct enthalpies of vaporization and boiling point of those elements ( $\mathrm{Tb}, \mathrm{Hf}, \mathrm{Ir}, \mathrm{Mo}, \mathrm{Sb}, \mathrm{Si}$, and $\mathrm{Zr}$ ). The predicted and closest recorded values for both boiling point and enthalpies of vaporization for category III now differ by less than $10 \%$ (Table 10).

Finally, after the correction made for data in category I, category II, and category III, two new ANNs were trained with the "corrected" values inserted (shown in Table 11), and the results are shown in Figure 2. For forward and backward predictions, respectively, statistics are given in the third and fourth rows of Table 12. To make the comparison, the statistical analysis for Figure 1 is shown in the first and second row of Table 12. After correction, the moduli have decreased dramatically.

In this method, all that is required is a sufficient correlation, which can itself be established by the ANNs that are then employed to discriminate between the majority of wellcorrelated data points and an outlying minority. Further, more than two properties can be correlated, and the details of the procedures for doing so have been discussed. ${ }^{8}$ It also needs to be pointed out that the "consistent" data in all handbooks does not necessarily mean they are "correct". However, the ANN could detect them if they do not follow the trend. It is arguable that the term "outlier" should not be used to justify a predictive replacement, for it is often the case that unusual results are indicators of new knowledge. ${ }^{16}$

It needs to be pointed out that the boiling point and enthalpy of vaporization are indirectly related based on the Clausius-Clapeyron equation $\left(\mathrm{d} P_{\text {vap }} / \mathrm{d} T\right)=\left(\Delta_{\text {vap }} H_{\mathrm{m}}\right) /\left(T \Delta V_{\text {vap }}\right)=\left(\Delta_{\text {vap }} H_{\mathrm{m}}\right) /\left(\left(R T^{2} /\right.\right.$ $\left.\left.P_{\text {vap }}\right) \Delta Z_{\text {vap }}\right)$, which in its integrated form gives $P_{\text {vap }}=i$ 
Table 2. List of Enthalpies of Vaporization Divided by $\mathbf{k J} \cdot \mathrm{mol}^{-1}$ from Five Handbooks ${ }^{a}$

\begin{tabular}{|c|c|c|c|c|c|c|}
\hline element & $\mathrm{CDB}$ & LAG & ELE & TPC & CRC & $(\max / \min -1) \cdot 100 \%$ \\
\hline $\mathrm{Ag}^{b}$ & 254 & 258 & 255 & 25.5 & - & $912 \%$ \\
\hline $\mathrm{Al}^{b}$ & 284 & 294 & 294 & 29.1 & 294 & $910 \%$ \\
\hline $\mathrm{Ar}$ & 6.53 & 6.43 & 6.53 & 6.52 & 6.43 & $1.56 \%$ \\
\hline $\mathrm{Au}$ & 342 & 324 & 324 & 324 & 324 & $5.56 \%$ \\
\hline $\mathrm{Ba}^{c}$ & 149 & 140 & 151 & 140 & 140 & $7.86 \%$ \\
\hline $\mathrm{Be}^{c}$ & 309 & 297 & 309 & 298 & - & $4.04 \%$ \\
\hline $\mathrm{B}^{b}$ & 540 & 480 & 539 & 508 & 480 & $12.50 \%$ \\
\hline $\mathrm{C}(\text { graphite })^{c}$ & 715 & - & 711 & - & - & $0.56 \%$ \\
\hline $\mathrm{Ca}$ & 153 & 155 & 150 & 155 & - & $3.33 \%$ \\
\hline $\mathrm{Cd}$ & 100 & 99.9 & 99.9 & 99.9 & 99.9 & $0.10 \%$ \\
\hline $\mathrm{Ce}^{b}$ & - & 398 & 314 & 314 & - & $26.80 \%$ \\
\hline $\mathrm{Cl}$ & 20.4 & 20.4 & 20.4 & 20.4 & 20.4 & $0.00 \%$ \\
\hline Co & 390 & 377 & 382 & 373 & - & $4.56 \%$ \\
\hline $\mathrm{Eu}$ & - & 176 & 176 & 176 & - & $0.00 \%$ \\
\hline $\mathrm{F}$ & 6.32 & 6.62 & 6.55 & 6.54 & 6.62 & $4.75 \%$ \\
\hline $\mathrm{Fe}$ & 354 & 340 & 351 & 350 & - & $4.12 \%$ \\
\hline $\mathrm{Ga}$ & 256 & 254 & 256 & 256 & 254 & $0.79 \%$ \\
\hline $\mathrm{Gd}$ & - & 301.3 & 311.7 & 311.7 & - & $3.45 \%$ \\
\hline $\mathrm{Ge}$ & 330 & 334 & 334 & 334 & 334 & $1.21 \%$ \\
\hline $\mathrm{H}$ & 0.9 & - & 0.92 & 0.9 & 0.9 & $2.22 \%$ \\
\hline $\mathrm{He}$ & 0.084 & 0.083 & 0.082 & 0.08 & 0.08 & $5.00 \%$ \\
\hline $\mathrm{Hf}^{d}$ & 648 & 571 & 661 & 661 & - & $15.80 \%$ \\
\hline $\mathrm{Hg}$ & 58.2 & 59.1 & 59.2 & 59.1 & 59.1 & $1.72 \%$ \\
\hline $\mathrm{Ho}^{b}$ & - & 71 & 251 & 251 & - & $254 \%$ \\
\hline $\mathrm{I}\left(\mathrm{I}_{2}\right)^{b}$ & 22 & 41.6 & 41.7 & 41.9 & 41.6 & $90.50 \%$ \\
\hline In & 225 & 232 & 226 & 226 & - & $3.11 \%$ \\
\hline $\operatorname{Ir}^{d}$ & 636 & 232 & 564 & 564 & - & $174 \%$ \\
\hline $\mathrm{N}$ & 5.58 & 5.57 & 5.58 & 5.59 & 5.57 & $0.36 \%$ \\
\hline $\mathrm{Na}^{b}$ & 101 & 97.4 & 89 & 97.4 & - & $13.50 \%$ \\
\hline $\mathrm{Nb}^{c}$ & 694 & 690 & 697 & 690 & - & $1.01 \%$ \\
\hline $\mathrm{Nd}$ & - & 289 & 284 & 284 & - & $1.76 \%$ \\
\hline $\mathrm{Ne}$ & 1.8 & 1.71 & 1.74 & 1.77 & 1.71 & $5.26 \%$ \\
\hline $\mathrm{Ni}$ & 379 & 378 & 372 & 378 & - & $1.88 \%$ \\
\hline $\mathrm{O}$ & 6.82 & 6.82 & 6.82 & 6.82 & 6.82 & $0.00 \%$ \\
\hline $\mathrm{Os}^{b}$ & 678 & 738 & 628 & 628 & - & $17.50 \%$ \\
\hline $\mathrm{P}(\text { white })^{b}$ & 12.4 & 12.4 & 51.9 & - & 12.4 & $319 \%$ \\
\hline $\mathrm{Pb}$ & 177 & 180 & 179 & 178 & 180 & $1.69 \%$ \\
\hline $\mathrm{Pd}^{c}$ & 380 & 362 & 393 & 393 & - & $8.56 \%$ \\
\hline $\operatorname{Pr}^{c}$ & - & 331 & 333 & 333 & - & $0.60 \%$ \\
\hline $\mathrm{Pt}$ & 510 & 469 & 511 & 511 & - & $8.96 \%$ \\
\hline $\mathrm{Rb}$ & 69 & 75.8 & 69.2 & 69.2 & - & $9.86 \%$ \\
\hline $\operatorname{Re}^{b}$ & 636 & 704 & 707 & 707 & - & $11.20 \%$ \\
\hline $\mathrm{Rh}^{c}$ & 531 & 494 & 495 & 495 & - & $7.49 \%$ \\
\hline $\mathrm{Ru}$ & 619 & 592 & 568 & 568 & - & $8.98 \%$ \\
\hline $\mathrm{S}(\text { monoclinic })^{b}$ & 10 & 45 & 9.62 & - & 45 & $368 \%$ \\
\hline $\mathrm{Sb}^{d}$ & 195 & 193 & 67.9 & 67.9 & - & $187 \%$ \\
\hline $\mathrm{Sc}$ & 310 & 333 & 305 & 305 & - & $9.18 \%$ \\
\hline $\mathrm{Se}^{b}$ & 14 & 95.5 & 26.3 & 26.3 & 95.5 & $582 \%$ \\
\hline $\mathrm{Si}^{d}$ & 300 & 359 & 383 & 359 & - & $27.70 \%$ \\
\hline $\mathrm{Sm}^{b}$ & - & 165 & 192 & 192 & - & $16.40 \%$ \\
\hline $\mathrm{Sn}^{c}$ & 290 & 296 & 290 & 290 & - & $2.07 \%$ \\
\hline $\mathrm{Sr}$ & 141 & 137 & 139 & 137 & - & $2.92 \%$ \\
\hline $\mathrm{Ta}$ & 753 & 733 & 753 & 737 & - & $2.73 \%$ \\
\hline $\mathrm{Tb}^{d}$ & - & 293 & 391 & - & - & $33.50 \%$ \\
\hline $\mathrm{Te}^{b}$ & 49.8 & 114 & 50.6 & 50.6 & 114 & $129 \%$ \\
\hline
\end{tabular}


Table 2. Continued

\begin{tabular}{|c|c|c|c|c|c|c|}
\hline element & $\mathrm{CDB}$ & LAG & ELE & $\mathrm{TPC}$ & $\mathrm{CRC}$ & $(\max / \min -1) \cdot 100 \%$ \\
\hline $\mathrm{Xe}$ & 12.6 & 12.6 & 12.7 & 12.6 & 12.6 & $0.79 \%$ \\
\hline $\mathrm{Yb}^{c}$ & - & 159 & 159 & - & - & $0.00 \%$ \\
\hline $\mathrm{Y}^{c}$ & 390 & 365 & 393 & 393 & - & $7.67 \%$ \\
\hline $\mathrm{Zn}$ & 115 & 124 & 115 & 115 & - & $7.83 \%$ \\
\hline $\mathrm{Zr}^{d}$ & 502 & 573 & 582 & 591 & - & $17.70 \%$ \\
\hline
\end{tabular}

${ }^{a}$ Acronyms as in text. This table does not have exclusions based on judgement. The elements are sorted in alphabetical order. ${ }^{b}$ Category I: the data for the boiling point for these elements are consistent in different handbooks, but those for the enthalpy of vaporization are not. ${ }^{c}$ Category II: the data for the enthalpy of vaporization for these elements are consistent in different handbooks, but those of the boiling point are not. ${ }^{d}$ Category III: the data for neither the boiling point nor the enthalpy of vaporization for these elements are consistent in different handbooks.

Table 3. Data Set First Used to Train the ANNs Shown in Figure $\mathbf{1}^{a}$

\begin{tabular}{|c|c|c|c|c|c|c|c|c|}
\hline & $T_{\mathrm{b}}$ & $\Delta_{\mathrm{vap}} H_{\mathrm{m}}$ & & $T_{\mathrm{b}}$ & $\Delta_{\mathrm{vap}} H_{\mathrm{m}}$ & & $T_{\mathrm{b}}$ & $\Delta_{\mathrm{vap}} H_{\mathrm{m}}$ \\
\hline element & $\mathrm{K}$ & $\overline{\mathrm{kJ}} \cdot \mathrm{mol}^{-1}$ & element & $\mathrm{K}$ & $\mathrm{kJ} \cdot \mathrm{mol}^{-1}$ & element & $\mathrm{K}$ & $\mathrm{kJ} \cdot \mathrm{mol}^{-1}$ \\
\hline $\mathrm{Ag}$ & 2483 & 254 & $\mathrm{H}$ & 21.15 & 0.90 & $\operatorname{Pr}$ & 3403 & 331 \\
\hline $\mathrm{Al}$ & 2743 & 284 & $\mathrm{He}$ & 4.150 & 0.08 & $\mathrm{Pt}$ & 4803 & 510 \\
\hline $\mathrm{Ar}$ & 87.20 & 6.53 & $\mathrm{Hf}$ & 5673 & 648 & $\mathrm{Rb}$ & 961.2 & 69.0 \\
\hline As (gray) & 886.2 & 32.4 & $\mathrm{Hg}$ & 630.2 & 59.1 & $\mathrm{Re}$ & 5903 & 636 \\
\hline $\mathrm{Au}$ & 3243 & 342 & Ho & 2873 & 71.0 & $\mathrm{Rh}$ & 4773 & 531 \\
\hline B & 4203 & 540 & $\mathrm{I}\left(\mathrm{I}_{2}\right)$ & 457.2 & 22.0 & $\mathrm{Ru}$ & 5173 & 619 \\
\hline $\mathrm{Ba}$ & 1913 & 149 & In & 2273 & 225 & S (mono.) & 718.2 & 10.0 \\
\hline $\mathrm{Be}$ & 2750 & 309 & $\mathrm{Ir}$ & 5573 & 636 & $\mathrm{Sb}$ & 1653 & 195 \\
\hline $\mathrm{Bi}$ & 1833 & 179 & $\mathrm{~K}$ & 1047 & 79.1 & $\mathrm{Sc}$ & 3003 & 310 \\
\hline $\mathrm{Br}$ & 331.7 & 30.0 & $\mathrm{Kr}$ & 121.2 & 9.04 & $\mathrm{Se}$ & 958.2 & 14.0 \\
\hline $\mathrm{C}$ (graphite) & 5103 & 715 & $\mathrm{La}$ & 3743 & 400 & $\mathrm{Si}$ & 2633 & 300 \\
\hline $\mathrm{Ca}$ & 1760 & 153 & $\mathrm{Li}$ & 1603 & 136 & $\mathrm{Sm}$ & 2173 & 165 \\
\hline $\mathrm{Cd}$ & 1038 & 100 & $\mathrm{Lu}$ & 3603 & 414 & $\mathrm{Sn}$ & 2543 & 290 \\
\hline $\mathrm{Ce}$ & 3743 & 398 & $\mathrm{Mg}$ & 1383 & 132 & $\mathrm{Sr}$ & 1653 & 141 \\
\hline $\mathrm{Cl}$ & 238.5 & 20.4 & $\mathrm{Mn}$ & 2373 & 225 & $\mathrm{Ta}$ & 5693 & 753 \\
\hline $\mathrm{Co}$ & 3173 & 390 & Mo & 5833 & 536 & $\mathrm{~Tb}$ & 3073 & 293 \\
\hline $\mathrm{Cr}$ & 2755 & 347 & $\mathrm{~N}$ & 77.15 & 5.58 & $\mathrm{Te}$ & 1263 & 49.8 \\
\hline Cs & 963.2 & 66.1 & $\mathrm{Na}$ & 1163 & 101 & $\mathrm{Ti}$ & 3533 & 427 \\
\hline $\mathrm{Cu}$ & 2868 & 305 & $\mathrm{Nb}$ & 3573 & 694 & $\mathrm{Tl}$ & 1733 & 162 \\
\hline Dy & 2873 & 280 & $\mathrm{Nd}$ & 3303 & 289 & $\mathrm{Tm}$ & 2003 & 247 \\
\hline $\mathrm{Er}$ & 3173 & 280 & $\mathrm{Ne}$ & 27.15 & 1.80 & V & 3273 & 444 \\
\hline $\mathrm{Eu}$ & 1713 & 176 & $\mathrm{Ni}$ & 3003 & 379 & $\mathrm{~W}$ & 6203 & 774 \\
\hline $\mathrm{F}$ & 85.15 & 6.32 & $\mathrm{O}$ & 90.15 & 6.82 & $\mathrm{Xe}$ & 165.2 & 12.6 \\
\hline $\mathrm{Fe}$ & 3273 & 354 & Os & 5273 & 678 & $\mathrm{Y}$ & 3203 & 390 \\
\hline $\mathrm{Ga}$ & 2673 & 256 & $\mathrm{P}$ (white) & 553.2 & 12.4 & $\mathrm{Yb}$ & 1703 & 159 \\
\hline Gd & 3273 & 301 & $\mathrm{~Pb}$ & 2017 & 177 & $\mathrm{Zn}$ & 1180 & 115 \\
\hline $\mathrm{Ge}$ & 3103 & 330 & $\mathrm{Pd}$ & 4253 & 380 & $\mathrm{Zr}$ & 3853 & 502 \\
\hline
\end{tabular}

${ }^{a}$ The majority were taken from the Chemistry Data Book (CDB) without judgement. A few data unavailable in CDB were taken from LAG and ELE. ( $T_{\mathrm{b}}$ : boiling point; $\Delta_{\mathrm{vap}} H_{\mathrm{m}}$ : enthalpy of vaporization).

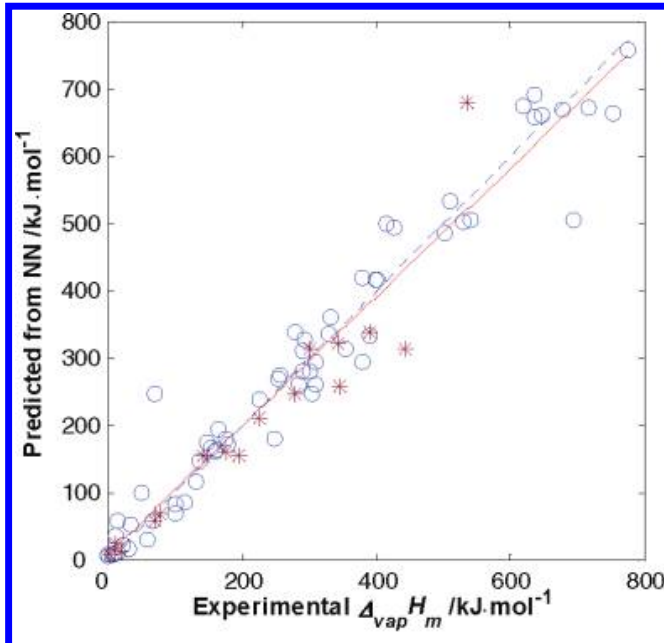

(a)

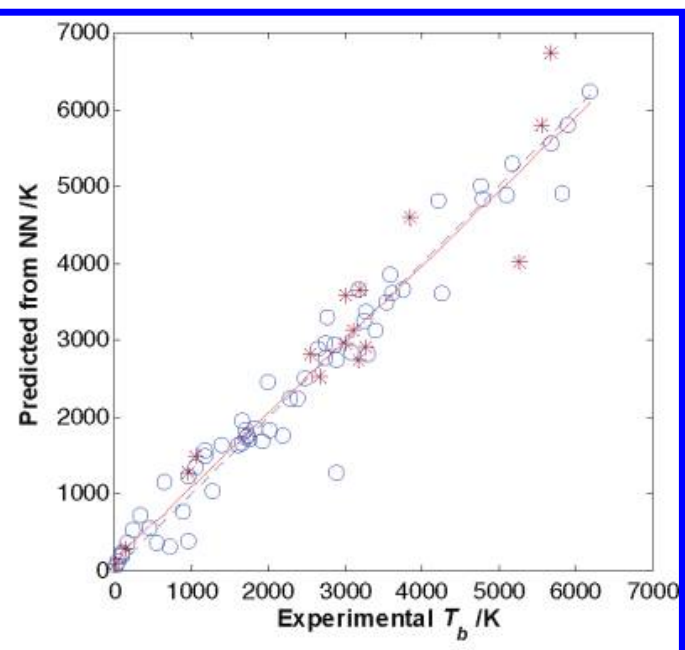

(b)

Figure 1. Prediction of (a) enthalpy of vaporization $\left(\Delta_{\mathrm{vap}} H_{\mathrm{m}}\right)$ from boiling point $\left(T_{\mathrm{b}}\right), R=0.973$; (b) boiling point $\left(T_{\mathrm{b}}\right)$ from enthalpy of vaporization $\left(\Delta_{\mathrm{vap}} H_{\mathrm{m}}\right), R=0.972$; using data from CDB, LAG, and ELE. $\bigcirc$, training data points; $*$, test data points; - , best linear fit; ----, exp. $=$ prediction.

$\exp \left[\left(\Delta_{\text {vap }} H_{\mathrm{m}}\right) /(R T)\right]$, and the boiling point is the temperature at which $P_{\text {vap }}$ reaches ambient ( $i$ is a constant of integration). ${ }^{17}$ The pre-exponential coefficient is not directly related. The ANN can find clusters of properties that are indirectly related in this way to identify suspect data.
Verification of the Method by Referring to Original Sources. To verify the method, original sources were consulted where possible to (1) check whether the refined values were sensible, (2) to reveal and analyze the origin of the differences between handbook data, and (3) to find whether the neural 
Table 4. List of Category I Elements: Boiling Points of the Elements Are Consistent, but Enthalpies of Vaporization Are Inconsistent

\begin{tabular}{|c|c|c|c|c|c|c|c|}
\hline \multirow[b]{2}{*}{ element } & \multirow{2}{*}{$\begin{array}{l}T_{\mathrm{b}} \\
\mathrm{K}\end{array}$} & \multicolumn{6}{|c|}{$\Delta_{\mathrm{vap}} H_{\mathrm{m}} / \mathrm{kJ} \cdot \mathrm{mol}^{-1}$} \\
\hline & & $\mathrm{CDB}$ & LAG & ELE & TPC & $\mathrm{CRC}$ & $(\max / \min -1) \cdot 100 \%$ \\
\hline $\mathrm{Ag}$ & 2483 & 254 & 258 & 255 & 25.5 & - & $912 \%$ \\
\hline $\mathrm{Al}$ & 2743 & 284 & 294 & 294 & 29.1 & 294 & $910 \%$ \\
\hline $\mathrm{Bi}$ & 1833 & 179 & 151 & 179 & 187 & 151 & $23.8 \%$ \\
\hline $\mathrm{Ce}$ & 3743 & - & 398 & 314 & 314 & - & $26.8 \%$ \\
\hline Ho & 2873 & - & 71 & 251 & 251 & - & $254 \%$ \\
\hline $\mathrm{Na}$ & 1163 & 101 & 97.4 & 89 & 97.4 & - & $13.5 \%$ \\
\hline Os & 5273 & 678 & 738 & 628 & 628 & - & $17.5 \%$ \\
\hline P (white) & 553.2 & 12.4 & 12.4 & 51.9 & - & 12.4 & $319 \%$ \\
\hline $\mathrm{Re}$ & 5903 & 636 & 704 & 707 & 707 & - & $11.2 \%$ \\
\hline S & 718.2 & 10 & 45 & 9.62 & - & 45 & $368 \%$ \\
\hline $\mathrm{Se}$ & 958.2 & 14 & 95.5 & 26.3 & 26.3 & 95.5 & $582 \%$ \\
\hline $\mathrm{Sm}$ & 2173 & - & 165 & 192 & 192 & - & $16.4 \%$ \\
\hline
\end{tabular}

Table 5. List of Category II Elements: Enthalpies of Vaporization Are Consistent, but Boiling Points Are Inconsistent

\begin{tabular}{|c|c|c|c|c|c|c|c|}
\hline \multirow[b]{2}{*}{ element } & \multirow{2}{*}{$\frac{\Delta_{\mathrm{vap}} H_{\mathrm{m}}}{\mathrm{kJ} \cdot \mathrm{mol}^{-1}}$} & \multicolumn{6}{|c|}{$T_{\mathrm{b}} / \mathrm{K}$} \\
\hline & & $\mathrm{CDB}$ & LAG & ELE & TPC & $\mathrm{CRC}$ & $(\max / \min -1) \cdot 100 \%$ \\
\hline $\mathrm{Ba}$ & 149 & 1913 & 1913 & 1910 & 2173 & 2170 & $13.8 \%$ \\
\hline $\mathrm{Be}$ & 309 & 2750 & 2750 & 3243 & 2743 & 2744 & $18.2 \%$ \\
\hline $\mathrm{Nb}$ & 694 & 3573 & 3573 & 5015 & 4973 & 5017 & $40.4 \%$ \\
\hline $\mathrm{Pd}$ & 380 & 4253 & 4253 & 3413 & 3233 & 3236 & $31.6 \%$ \\
\hline $\operatorname{Pr}$ & 331 & 3403 & 3403 & 3785 & 3783 & 3793 & $11.5 \%$ \\
\hline $\mathrm{Tm}$ & 247 & 2003 & 2003 & 2220 & 2223 & 2223 & $11.0 \%$ \\
\hline V & 444 & 3273 & 3273 & 3650 & 3673 & 3680 & $12.4 \%$ \\
\hline Y & 390 & 3203 & 3203 & 3611 & 3613 & 3618 & $13.0 \%$ \\
\hline $\mathrm{Yb}$ & 159 & 1703 & 1703 & 1466 & 1473 & 1469 & $16.2 \%$ \\
\hline average & & & & & & & $18.9 \%$ \\
\hline
\end{tabular}

Table 6. List of Category III Elements: Both Boiling Points and Enthalpies of Vaporization Are Inconsistent

\begin{tabular}{|c|c|c|c|c|c|c|c|c|c|c|}
\hline \multirow[b]{2}{*}{ element } & \multicolumn{5}{|c|}{$T_{\mathrm{b}} / \mathrm{K}$} & \multicolumn{5}{|c|}{$\Delta_{\mathrm{vap}} H_{\mathrm{m}} / \mathrm{kJ} \cdot \mathrm{mol}^{-1}$} \\
\hline & CDB & LAG & ELE & TPC & $\mathrm{CRC}$ & $\mathrm{CDB}$ & LAG & ELE & $\mathrm{TPC}$ & $\mathrm{CRC}$ \\
\hline $\mathrm{Tb}$ & 3073 & 3073 & 3396 & 3493 & 3503 & - & 293 & 391 & - & - \\
\hline $\mathrm{Hf}$ & 5673 & 5673 & 5470 & 4873 & 4876 & 648 & 571 & 661 & 661 & - \\
\hline $\mathrm{Ir}$ & 5573 & 5573 & 4403 & 4703 & 4701 & 636 & 232 & 564 & 564 & - \\
\hline Mo & 5833 & 5833 & 4885 & 4913 & 4912 & 536 & 617 & 594 & 590 & - \\
\hline $\mathrm{Sb}$ & 1653 & 1653 & 1908 & 1860 & 1860 & 195 & 193 & 67.9 & 67.9 & - \\
\hline $\mathrm{Si}$ & 2633 & 2633 & 2628 & 3533 & 3538 & 300 & 359 & 383 & 359 & - \\
\hline $\mathrm{Zr}$ & 3853 & 3853 & 4650 & 4673 & 4682 & 502 & 573 & 582 & 591 & - \\
\hline
\end{tabular}

network can give values closer to the original literature. Some errors are quickly attributable to incorrect unit conversions or to misplaced decimal points, but some arise from different reference conditions, and representative examples are shown below

Table 8 indicates that predicted and closest recorded values of enthalpy of vaporization for most elements differ by less than $10 \%$ after removal of incorrect data. The exceptions are I (15.6 $\%)$, P (17.2 \%), Se (17.9\%), Ho (19.1\%), and S (26.7\%). Data for elements I, $\mathrm{P}$, and $\mathrm{S}$ depend on the polyatomic nature of these molecules; this accounts for the differences shown in Table 2, but handbooks do not always state how the value is normalized. Because I, P, and S exist in polyatomic molecular forms, the values for polyatomic forms should be clarified. From Table 8 , it is seen that the neural networks have a capability to locate values which are in the right magnitude, although the difference is still greater than $10 \%$. However, the values for Ho and Se need more detailed investigation.

Ho. The predicted enthalpy of vaporization of holmium by ANN is $299 \mathrm{~kJ} \cdot \mathrm{mol}^{-1}$, and the values in handbooks are 71 $\mathrm{kJ} \cdot \mathrm{mol}^{-1}(\mathrm{LAG}), 251 \mathrm{~kJ} \cdot \mathrm{mol}^{-1}(\mathrm{ELE})$, and $251 \mathrm{~kJ} \cdot \mathrm{mol}^{-1}(\mathrm{TPC})$ (no record in CDB and CRC for Ho). If we select $251 \mathrm{~kJ} \cdot \mathrm{mol}^{-1}$ as a correct value, this gives a $19.1 \%$ deviation between ANN prediction and the handbook value. From the following analysis and search of original papers, we believe the ANN prediction is more accurate than the handbook.

There are two sources of discrepancy. The first is the unit of the values. Original research papers offer the values for $\Delta_{\mathrm{vap}} H_{\mathrm{m}, \mathrm{st}}$ : $301 \mathrm{~kJ} \cdot \mathrm{mol}^{-1}\left(71910 \mathrm{cal} \cdot \mathrm{mol}^{-1}\right),{ }^{18} 291 \mathrm{k} \mathrm{J} \cdot \mathrm{mol}^{-1}(69500$ $\left.\mathrm{cal} \cdot \mathrm{mol}^{-1}\right){ }^{19} 314 \mathrm{~kJ} \cdot \mathrm{mol}^{-1}\left(75040 \mathrm{cal} \cdot \mathrm{mol}^{-1}\right){ }^{20} 339 \mathrm{~kJ} \cdot \mathrm{mol}^{-1}$ $\left(81150 \mathrm{cal} \cdot \mathrm{mol}^{-1}\right){ }^{18}$ and $295 \mathrm{~kJ} \cdot \mathrm{mol}^{-1}\left(70600 \mathrm{cal} \cdot \mathrm{mol}^{-1}\right){ }^{21}$ Clearly these results indicate that the enthalpy of vaporization of holmium is around $297 \mathrm{~kJ} \cdot \mathrm{mol}^{-1}$ (which is very close to $299 \mathrm{~kJ} \cdot \mathrm{mol}^{-1}$ predicted by ANN), rather than the $71 \mathrm{~kJ} \cdot \mathrm{mol}^{-1}$ (the number in LAG but the unit is different) recorded in LAG, and the source of error is the transcription of units. Indeed, in the earlier 12th edition of Lange's Handbook Chemistry, ${ }^{22}$ the value was $251 \mathrm{~kJ} \cdot \mathrm{mol}^{-1}\left(60 \mathrm{kcal} \cdot \mathrm{mol}^{-1}\right)$, placing it in the correct range.

The second source of discrepancy is the reference temperature. The values from the research papers listed above are corrected to standard temperature. However, the category IV 
Table 7. List of Category IV Elements: Both Boiling Points and Enthalpies of Vaporization Are Consistent

\begin{tabular}{|c|c|c|c|c|c|}
\hline & $T_{\mathrm{b}}$ & $\underline{\Delta_{\text {vap }} H_{\mathrm{m}}}$ & & $T_{\mathrm{b}}$ & $\underline{\Delta_{\text {vap }} H_{\mathrm{m}}}$ \\
\hline element & $\mathrm{K}$ & $\mathrm{kJ} \cdot \mathrm{mol}^{-1}$ & element & $\mathrm{K}$ & $\mathrm{kJ} \cdot \mathrm{mol}^{-1}$ \\
\hline $\mathrm{Ar}$ & 87.15 & 6.53 & K & 1047 & 79.1 \\
\hline $\mathrm{Au}$ & 3243 & 342 & $\mathrm{Li}$ & 1603 & 136 \\
\hline $\mathrm{Br}$ & 331.7 & 30.0 & $\mathrm{Lu}$ & 3603 & 414 \\
\hline $\mathrm{Ca}$ & 1760 & 153 & $\mathrm{Mg}$ & 1383 & 132 \\
\hline $\mathrm{Cd}$ & 1038 & 100 & $\mathrm{Mn}$ & 2373 & 225 \\
\hline $\mathrm{Cr}$ & 2755 & 347 & $\mathrm{Ne}$ & 27.15 & 1.90 \\
\hline Cs & 963.2 & 66.1 & $\mathrm{Ni}$ & 3003 & 379 \\
\hline $\mathrm{Cu}$ & 2868 & 305 & $\mathrm{O}$ & 90.15 & 6.82 \\
\hline Dy & 2873 & 280 & $\mathrm{~Pb}$ & 2017 & 177 \\
\hline $\mathrm{Er}$ & 3173 & 280 & $\mathrm{Pt}$ & 4100 & 510 \\
\hline $\mathrm{Eu}$ & 1713 & 176 & $\mathrm{Rb}$ & 961.2 & 69.0 \\
\hline $\mathrm{F}$ & 85.15 & 6.32 & $\mathrm{Ru}$ & 4423 & 619 \\
\hline $\mathrm{H}$ & 21.15 & 0.90 & $\mathrm{Tl}$ & 1733 & 162 \\
\hline $\mathrm{He}$ & 4.15 & 0.0840 & W & 6203 & 774 \\
\hline $\mathrm{Hg}$ & 630.2 & 58.2 & $\mathrm{Xe}$ & 165.2 & 12.6 \\
\hline In & 2273 & 225 & $\mathrm{Zn}$ & 1180 & 115 \\
\hline
\end{tabular}

Table 8. List of Category I Elements with Predicted and Selected Correct Values of Enthalpy of Vaporization and Difference Percentage

\begin{tabular}{|c|c|c|c|c|}
\hline \multirow[b]{2}{*}{ element } & $T_{\mathrm{b}}$ & $\begin{array}{l}\text { predicted enthalpy } \\
\text { of vaporization } \\
\end{array}$ & $\begin{array}{l}\text { selected enthalpy } \\
\text { of vaporization } \\
\end{array}$ & \multirow[b]{2}{*}{$\begin{array}{l}\text { difference } \\
\text { percentage }\end{array}$} \\
\hline & K & $\mathrm{kJ} \cdot \mathrm{mol}^{-1}$ & $\mathrm{~kJ} \cdot \mathrm{mol}^{-1}$ & \\
\hline $\mathrm{Na}$ & 1163 & 97.6 & 97.4 & $0.21 \%$ \\
\hline $\mathrm{Al}$ & 2743 & 281 & 284 & $1.06 \%$ \\
\hline B & 4203 & 499 & 508 & $1.77 \%$ \\
\hline Os & 5273 & 664 & 678 & $2.06 \%$ \\
\hline $\mathrm{Kr}$ & 121.2 & 8.8 & 9.03 & $2.55 \%$ \\
\hline $\mathrm{Ag}$ & 2483 & 246 & 254 & $3.15 \%$ \\
\hline $\mathrm{Te}$ & 1263 & 107 & 114 & $6.14 \%$ \\
\hline $\mathrm{Bi}$ & 1833 & 168 & 179 & $6.15 \%$ \\
\hline $\mathrm{Re}$ & 5903 & 752 & 707 & $6.36 \%$ \\
\hline $\mathrm{Ce}$ & 3743 & 427 & 398 & $7.29 \%$ \\
\hline Sm & 2173 & 207 & 192 & $7.81 \%$ \\
\hline $\mathrm{I}_{2}$ & 457.2 & 35.1 & 41.6 & $15.6 \%$ \\
\hline $\mathrm{P}$ (white) & 553.2 & 43 & 51.9 & $17.2 \%$ \\
\hline $\mathrm{Se}$ & 958.2 & 78.4 & 95.5 & $17.9 \%$ \\
\hline Ho & 2873 & 299 & 251 & $19.1 \%$ \\
\hline S & 718.2 & 57 & 45 & $\begin{array}{c}26.7 \% \\
8.81 \%\end{array}$ \\
\hline
\end{tabular}

Table 9. List of Category II Elements with Predicted and Selected Correct Values of the Boiling Point and Difference Percentage

\begin{tabular}{|c|c|c|c|c|}
\hline & $\Delta_{\mathrm{vap}} H_{\mathrm{m}}$ & $\begin{array}{c}\text { predicted } \\
\text { boiling point }\end{array}$ & $\begin{array}{c}\text { selected } \\
\text { boiling point }\end{array}$ & \\
\hline element & $\mathrm{kJ} \cdot \mathrm{mol}^{-1}$ & K & K & $\begin{array}{l}\text { difference } \\
\text { percentage }\end{array}$ \\
\hline $\mathrm{Pd}$ & 380 & 3221 & 3233 & $0.37 \%$ \\
\hline $\mathrm{Nb}$ & 694 & 5078 & 5017 & $1.22 \%$ \\
\hline $\mathrm{Yb}$ & 159 & 1671 & 1703 & $1.88 \%$ \\
\hline $\mathrm{Rh}$ & 531 & 4137 & 4000 & $3.43 \%$ \\
\hline $\mathrm{Y}$ & 390 & 3317 & 3203 & $3.56 \%$ \\
\hline C (graphite) & 715 & 5326 & 5103 & $4.37 \%$ \\
\hline $\mathrm{Be}$ & 309 & 3100 & 3243 & $4.41 \%$ \\
\hline $\mathrm{Sn}$ & 290 & 3060 & 2893 & $5.77 \%$ \\
\hline V & 444 & 3939 & 3680 & $7.04 \%$ \\
\hline $\operatorname{Pr}$ & 331 & 3081 & 3403 & $9.46 \%$ \\
\hline $\mathrm{Ba}$ & 149 & 1600 & 1910 & $16.2 \%$ \\
\hline $\begin{array}{l}\text { Tm } \\
\text { average }\end{array}$ & 247 & 2655 & 2223 & $\begin{array}{c}19.4 \% \\
6.43 \%\end{array}$ \\
\hline
\end{tabular}

values used for training ANNs 1 and 2 are all referenced to the boiling point (with the exception of four elements). Values for the enthalpy of vaporization of $\mathrm{Ho}$ at the boiling point are available: $:^{21,23} 280 \mathrm{~kJ} \cdot \mathrm{mol}^{-1}\left(67 \mathrm{kcal} \cdot \mathrm{mol}^{-1}\right)$ and $270 \mathrm{~kJ} \cdot \mathrm{mol}^{-1}$ $\left(64.7 \mathrm{kcal} \cdot \mathrm{mol}^{-1}\right)$. These values are close to the value predicted by the ANN (which is $299 \mathrm{~kJ} \cdot \mathrm{mol}^{-1}$ ), and this demonstrates the remarkable discernment of the ANN in detection of inconsistency and identification of true values.

Se. The handbook values are $(14,26.3$, and 95.5$) \mathrm{kJ} \cdot \mathrm{mol}^{-1}$, and the ANN predicts $78.4 \mathrm{~kJ} \cdot \mathrm{mol}^{-1}$ from the well-established boiling point of $958 \mathrm{~K}$. The source of $95.5 \mathrm{~kJ} \cdot \mathrm{mol}^{-1}$ can be found $^{24}$ and is supported by Hultgren et al. ${ }^{18}$ who gives a value at $625 \mathrm{~K}$ where, of the eight chemical allotropes for gaseous $\mathrm{Se}, \mathrm{Se}_{6}$ predominates. ${ }^{25}$ The value of $13.8 \mathrm{~kJ} \cdot \mathrm{mol}^{-1}$ for atomic Se corresponds to $82.8 \mathrm{~kJ} \cdot \mathrm{mol}^{-1}$ for $\mathrm{Se}_{6}{ }^{18}$ This may explain the handbook value of $14 \mathrm{~kJ} \cdot \mathrm{mol}^{-1}$ if that value is for atomic Se. The inconsistent handbook value of $26.3 \mathrm{~kJ} \cdot \mathrm{mol}^{-1}$ looks like a transcription of units error of $\mathrm{Se}_{6}$ by $4.18 \mathrm{~J} \cdot \mathrm{cal}^{-1}$ (i.e., should be $26.3 \mathrm{kcal} \cdot \mathrm{mol}^{-1}$ or $82.8 \mathrm{~kJ} \cdot \mathrm{mol}^{-1}$ ). The selected value of $95.5 \mathrm{~kJ} \cdot \mathrm{mol}^{-1}$ still deviates by more than $10 \%$ from the ANN predicted value $78.4 \mathrm{~kJ} \cdot \mathrm{mol}^{-1}$. A possible reason for this, as discussed by Bagnall ${ }^{25}$ and Reid et al., ${ }^{26}$ is associated with constants in the Clapeyron equation and is described in the following section.

Factors that Affect the Accuracy in the Prediction. In this section, the factors that affect the accuracy of prediction of boiling points and enthalpies of vaporization in this case can be identified as follows.

1. Determination of the Constant after Clausius-Clapeyron Integration. As mentioned in Reid et al., ${ }^{26}$ it is not easy to trace the origin of many experimental enthalpies of vaporization. A few were determined from calorimetric measurements, but in a large number of cases the values were obtained directly from Clausius-Clapeyron equation (d ln $\left.P_{\text {vap }}\right) /(\mathrm{d}(1 /$ $T))=-\left(\Delta H_{\mathrm{vap}}\right) /\left(R \Delta Z_{\mathrm{vap}}\right)$, in which the $\Delta Z_{\mathrm{vap}}$ were determined separately, and $\left(\mathrm{d} \ln P_{\text {vap }}\right) / \mathrm{d} T$ was found by numerical differentiation of experimental vapor pressure data or by differentiating some $P_{\text {vap }}-T$ correlation analytically. The constants in one equation may be optimized for correlating vapor pressures, but it does not necessarily follow that these same constants give the best fit for computing slopes. For this reason, the uncertainty is present in using any analytical vapor pressure-temperature equation to obtain accurate values of slopes $\left(\mathrm{d} \ln P_{\text {vap }}\right) / \mathrm{d} T$. 
Table 10. List of Category III Elements with Predicted and Selected Correct Values and the Difference Percentage (Only the Corrected Pairs Are Shown)

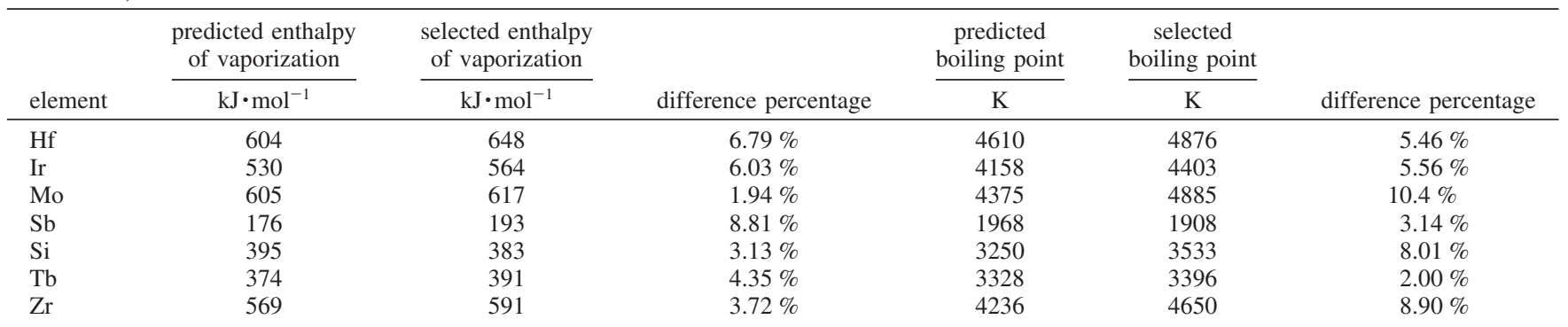

Table 11. List of "Corrected" Values (Including Data from Category IV and Corrected Category I, II, and III)

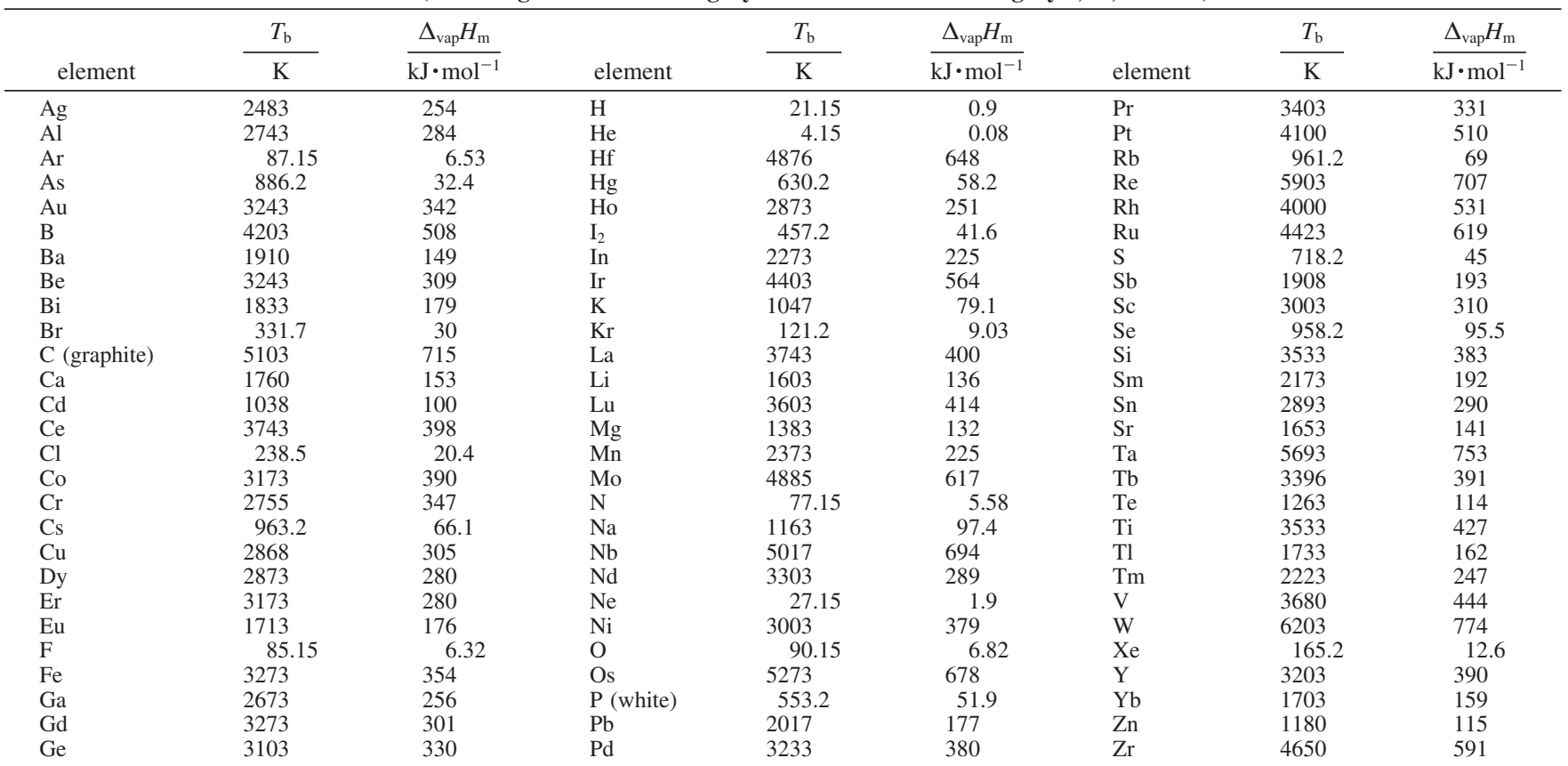

2. Enthalpy of Vaporization Varies with Temperature. $\Delta_{\mathrm{vap}} H_{\mathrm{m}}$ is always treated as a weak function of temperature, and an assumption is made that this value does not vary with temperature ${ }^{26,27}$ during the integration of the Clausius-Clapeyron equation. However, it is not true for each element. ${ }^{18}$ For some elements, the variation is narrow, such as Ga (from 258 $\mathrm{kJ} \cdot \mathrm{mol}^{-1}$ at normal boiling point to $272 \mathrm{~kJ} \cdot \mathrm{mol}^{-1}$ at room temperature, $5.2 \%$ difference), $\mathrm{Zr}$ (from $58 \mathrm{~kJ} \cdot \mathrm{mol}^{-1}$ at normal boiling point to $61 \mathrm{~kJ} \cdot \mathrm{mol}^{-1}$ at room temperature, $5.0 \%$ difference), $\mathrm{W}$ (from $823 \mathrm{~kJ} \cdot \mathrm{mol}^{-1}$ at normal boiling point to

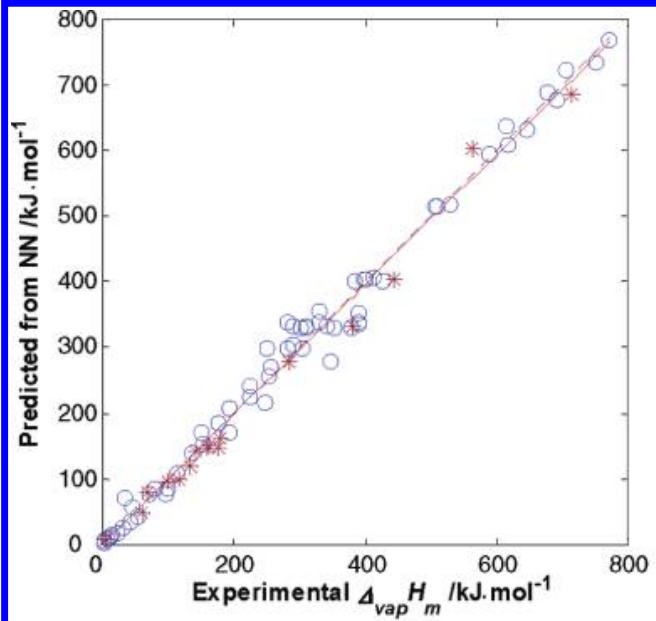

(a)

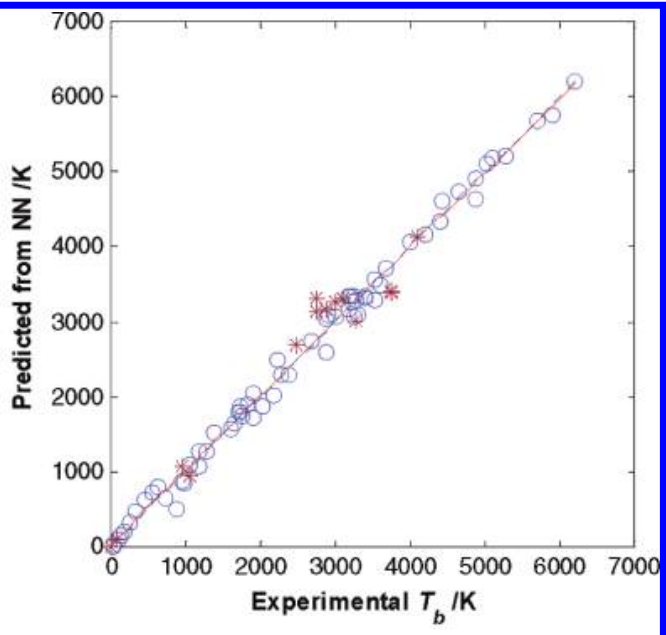

(b)

Figure 2. Prediction of (a) enthalpy of vaporization $\left(\Delta_{\mathrm{vap}} H_{\mathrm{m}}\right)$ from the boiling point $\left(T_{\mathrm{b}}\right)$; (b) the boiling point $\left(T_{\mathrm{b}}\right)$ from the enthalpy of vaporization $\left(\Delta_{\text {vap }} H_{\mathrm{m}}\right)$; using "consistent" data. $\bigcirc$, training data points; $*$, test data points; - , best linear fit; ----, exp. $=$ prediction. The general correlation performance has been increased, and the values of $M$ (the slope of the linear regression line) and $R$ are greater being $M=0.99, R=0.994$ and $M=0.993, R=0.995$ (for forward and backward predictions, respectively). 
Table 12. Statistical Analysis for ANN Performance in Figures 1 and 2

\begin{tabular}{|c|c|c|c|c|c|c|c|c|c|c|c|c|}
\hline \multirow[b]{2}{*}{ conditions } & \multicolumn{6}{|c|}{ test set } & \multicolumn{6}{|c|}{ whole set } \\
\hline & $M$ & $R$ & $\begin{array}{l}\text { mean of } \\
\text { error } \\
\text { modulus }\end{array}$ & $\begin{array}{l}\text { SD of error } \\
\text { modulus }\end{array}$ & $\begin{array}{c}\text { mean of } \\
\text { percentage } \\
\text { error } \\
\text { modulus/\% }\end{array}$ & $\begin{array}{c}\text { SD of } \\
\text { percentage } \\
\text { error } \\
\text { modulus/\% }\end{array}$ & $M$ & $R$ & $\begin{array}{c}\text { mean of } \\
\text { error modulus }\end{array}$ & $\begin{array}{l}\text { SD of error } \\
\text { modulus }\end{array}$ & $\begin{array}{c}\text { mean of } \\
\text { percentage } \\
\text { error } \\
\text { modulus/\% }\end{array}$ & $\begin{array}{c}\text { SD of } \\
\text { percentage } \\
\text { error } \\
\text { modulus/\% }\end{array}$ \\
\hline Figure 1a & 0.991 & 0.943 & $38.1 \mathrm{~kJ} \cdot \mathrm{mol}^{-1}$ & $44.1 \mathrm{~kJ} \cdot \mathrm{mol}^{-1}$ & 35.4 & 57.2 & 0.96 & 0.973 & $32.4 \mathrm{~kJ} \cdot \mathrm{mol}^{-1}$ & $36.9 \mathrm{~kJ} \cdot \mathrm{mol}^{-1}$ & 114 & 720 \\
\hline Figure $1 \mathrm{~b}$ & 0.982 & 0.954 & $409 \mathrm{~K}$ & $354 \mathrm{~K}$ & 36.9 & 64.1 & 0.963 & 0.972 & $269 \mathrm{~K}$ & $284 \mathrm{~K}$ & 45.9 & 139 \\
\hline Figure $2 \mathrm{a}$ & 0.986 & 0.995 & $18.1 \mathrm{~kJ} \cdot \mathrm{mol}^{-1}$ & $14.8 \mathrm{~kJ} \cdot \mathrm{mol}^{-1}$ & 10.1 & 6.38 & 0.99 & 0.994 & $16.7 \mathrm{~kJ} \cdot \mathrm{mol}^{-1}$ & $15.7 \mathrm{~kJ} \cdot \mathrm{mol}^{-1}$ & 48.5 & 308 \\
\hline Figure $2 b$ & 1 & 0.986 & $196 \mathrm{~K}$ & $167 \mathrm{~K}$ & 35.9 & 109 & 0.993 & 0.995 & $119 \mathrm{~K}$ & $108 \mathrm{~K}$ & 14.7 & 50.5 \\
\hline
\end{tabular}

$849 \mathrm{~kJ} \cdot \mathrm{mol}^{-1}$ at room temperature, $3.1 \%$ difference) but for others, the variation is wide, and the value of $\Delta_{\text {vap }} H_{\mathrm{m}}$ decreases with rising temperature, such as $\mathrm{Ba}$ (from $141 \mathrm{~kJ} \cdot \mathrm{mol}^{-1}$ at the normal boiling point to $182 \mathrm{~kJ} \cdot \mathrm{mol}^{-1}$ at room temperature, 28.7 $\%$ ) and $\mathrm{Tm}$ (from $191 \mathrm{~kJ} \cdot \mathrm{mol}^{-1}$ at the normal boiling point to $232 \mathrm{~kJ} \cdot \mathrm{mol}^{-1}$ at room temperature, $21.7 \%$ ). The data for the enthalpy of vaporization are recorded in many handbooks in a mixed fashion without mention of the temperatures to which the values apply. This introduces uncertainties in finding the correlation and reduces the accuracy of predictions. After comparing the values in Category IV with the values recorded in Selected Values of the Thermodynamic Properties of the Elements ${ }^{18}$ which tabulates enthalpies of vaporization over a temperature range, it is found that all but four (Dy, Eu, Gd, and $\mathrm{Lu}$ ) are recorded at the normal boiling points. Thus, $\mathrm{Pb}$ (Category IV), for example, has a value $175 \mathrm{~kJ} \cdot \mathrm{mol}^{-1}$ at the boiling point and $192 \mathrm{~kJ} \cdot \mathrm{mol}^{-1}$ at room temperature, ${ }^{18}$ and we infer that $177 \mathrm{~kJ} \cdot \mathrm{mol}^{-1}$ is the enthalpy of vaporization at the boiling point. Thus, neural networks (ANN1 and ANN2) have found the correlation between normal boiling points and the enthalpy of vaporization under normal boiling points.

3. Clausius-Clapeyron Equation Is Not the Only Equation for Estimating Enthalpies of Vaporization. Other methods such as Pitzer's acentric factor correlation, Riedel's method, Chen's method, and Vetere's method are also used. More accurate estimates may be obtained when specific correlations are employed and demand recourse to original sources.

These factors mean that differences between predicted and corrected values cannot be avoided. The first and third factors account for small differences $(<10 \%)$ since these just affect the accuracy of the enthalpies of vaporization. The large deviations $(>10 \%)$ may be attributed to the second factor. For Category I, the problems of the second factor do not attend the records of boiling point so the prediction of enthalpy of vaporization for these elements from the consistent boiling point can be treated as reliable. However, the second factor affects predictions for the elements in Category II; so enthalpies of vaporization used for these elements were rechecked with the values recorded in Selected Values of the Thermodynamic Properties of the Elements, ${ }^{18}$ and another set of predictions based on the enthalpy of vaporization referenced to the normal boiling point was made. The results are shown in Table 13 .

From the comparison of the results in Table 9 with Table 13, it can be seen that most of the boiling points are the same, except for $\mathrm{Yb}$ and $\mathrm{Tm}$. As a result, it is interesting to analyze which prediction is more sensible.

For $\mathrm{Yb}, 159 \mathrm{~kJ} \cdot \mathrm{mol}^{-1}$ is the value corresponding to room temperature according to Selected Values of the Thermodynamic Properties of the Elements on page 564, ${ }^{18}$ which gives 129 $\mathrm{kJ} \cdot \mathrm{mol}^{-1}$ at the normal boiling point and $152 \mathrm{~kJ} \cdot \mathrm{mol}^{-1}$ at room temperature. A higher value of enthalpy of vaporization at the normal boiling point corresponds to a higher value of the normal boiling point, so $159 \mathrm{~kJ} \cdot \mathrm{mol}^{-1}$ was used to predict the boiling point giving the higher value of boiling point for $\mathrm{Yb}$. Two
Table 13. List of Category II Elements with Predicted and Selected Correct Values of the Boiling Point and Difference Percentage (Record of Enthalpies of Vaporization under the Normal Boiling Point)

\begin{tabular}{|c|c|c|c|c|}
\hline element & $\frac{\Delta_{\mathrm{vap}} H_{\mathrm{m}}}{\mathrm{kJ} \cdot \mathrm{mol}^{-1}}$ & $\frac{\begin{array}{c}\text { predicted } \\
\text { boiling point }\end{array}}{\mathrm{K}}$ & $\frac{\begin{array}{c}\text { selected } \\
\text { boiling point }\end{array}}{\mathrm{K}}$ & $\begin{array}{l}\text { difference } \\
\text { percentage }\end{array}$ \\
\hline $\mathrm{Yb}$ & 129 & 1460 & 1466 & $0.41 \%$ \\
\hline $\mathrm{Nb}$ & 682 & 4944 & 4973 & $0.58 \%$ \\
\hline Y & 363 & 3111 & 3203 & $2.87 \%$ \\
\hline C (graphite) & 709 & 5254 & 5103 & $2.96 \%$ \\
\hline $\mathrm{Tm}$ & 191 & 1943 & 2003 & $3.00 \%$ \\
\hline $\mathrm{Rh}$ & 493 & 4144 & 4000 & $3.60 \%$ \\
\hline $\mathrm{Pd}$ & 358 & 3093 & 3233 & $4.33 \%$ \\
\hline $\mathrm{Be}$ & 292 & 3068 & 3243 & $5.40 \%$ \\
\hline $\mathrm{Sn}$ & 296 & 3081 & 2893 & $6.50 \%$ \\
\hline V & 451 & 3995 & 3680 & $8.56 \%$ \\
\hline $\operatorname{Pr}$ & 297 & 3084 & 3403 & $9.37 \%$ \\
\hline $\begin{array}{l}\text { Ba } \\
\text { average }\end{array}$ & 142 & 1551 & 1910 & $\begin{array}{c}18.8 \% \\
5.53 \%\end{array}$ \\
\hline
\end{tabular}

factors need to be considered: (1) For different elements, those having higher boiling points always have higher enthalpies of vaporization at the boiling point; (2) for a given element, the enthalpy of vaporization varies inversely with temperature. For $\mathrm{Yb}$, the boiling point is higher than ambient, and so the enthalpy of vaporization at the boiling point is lower than the value at ambience. Previously, the enthalpy of vaporization at room temperature was used to predict the boiling point, and the first factor means the boiling point was overestimated. Now the enthalpy of vaporization at the boiling point is employed, and the boiling point prediction is correct. Using $129 \mathrm{~kJ} \cdot \mathrm{mol}^{-1}$, the corresponding boiling point is $1460 \mathrm{~K}$, which is closer to 1466 $\mathrm{K}$ (within $0.40 \%$ ), and this value is confirmed by the work of Habermann and Daane. ${ }^{28}$ In their work, the vapor pressures of the rare-earth metals were measured by the Knudsen effusion technique using a quartz-fiber microbalance, and then a combination of second and third law methods were used to calculate the normal boiling point for each rare-earth metal, and for $\mathrm{Yb}$ this value is $1466( \pm 5) \mathrm{K}$.

For Tm, $247 \mathrm{~kJ} \cdot \mathrm{mol}^{-1}$ is the value corresponding to ambient temperature, according to Selected Values of the Thermodynamic Properties of the Elements on page $533,{ }^{18}$ which gives 191 $\mathrm{kJ} \cdot \mathrm{mol}^{-1}$ at the normal boiling point and $232 \mathrm{~kJ} \cdot \mathrm{mol}^{-1}$ at room temperature and is greater than the value recorded at the normal boiling point, which is about $191 \mathrm{~kJ} \cdot \mathrm{mol}^{-1}$. For similar reasons, $247 \mathrm{~kJ} \cdot \mathrm{mol}^{-1}$ was used to predict the boiling point producing a higher value. Using the value of $191 \mathrm{~kJ} \cdot \mathrm{mol}^{-1}$, it is found that the boiling point is $1943 \mathrm{~K}$, which is closer to $2003 \mathrm{~K}$ (within $3.00 \%$ ) and is consistent with the value obtained by Spedding et al. after purifying this element at the Ames Laboratory of the U.S. Atomic Energy Commission, ${ }^{29}$ which was $2000 \mathrm{~K}$.

From this analysis, the prediction of boiling point in these cases is more justifiable than before. So it emerges that although there are several factors, especially the second, that may mislead 
the neural network method, when care is taken and critical surveys are employed, it turns out to be robust and reliable.

\section{Conclusions}

The data in handbooks were thought to be very reliable, especially the data for elements in the periodic table. The ANN is able to find out many inconsistencies by a systematic and automatic method and the development of this technique. Its wider application and, more interestingly, its integration into databases as an immune system suggest that it may no longer be necessary to accept error rates at $5 \%$. The boiling point and enthalpy of vaporization of most elements (except radioactive elements) have been corrected in this paper, and the errors have brought down from a maximum of $900 \%$ to less than $10 \%$. Factors affecting the accuracy of the prediction have been discussed.

\section{Literature Cited}

(1) Cachadina, I.; Mulero, A. Vaporization Enthalpy: Corresponding-states Correlations versus DIPPR Database. J.Phys. Chem. Ref. Data 2007, 36, 1133-1139.

(2) Wei, W. Y.; Han, J. Y.; Xu, W. Group vector space method for estimating the normal boiling temperature and enthalpy of vaporization of organic compounds. J. Chem. Eng. Data 2004, 49, 1249-1253.

(3) Wei, W. Y.; Han, J. Y.; Xu, W. Group vector space method for estimating enthalpy of vaporization of organic compounds at the normal boiling point. J. Chem. Inf. Comput. Sci. 2004, 44, 1436-1439.

(4) Ericksen, D.; Wilding, W. V.; Oscarson, J. L.; Rowley, R. L. Use of the DIPPR database for development of QSPR correlations: Normal boiling point. J. Chem. Eng. Data 2002, 47, 1293-1302.

(5) Chrisman, N. R. The Error Component in Spatial Data. In Geographical Information Systems, Maguire, D. J., Goodchild, M. F., Rhind, D. W., Eds.; John Wiley \& Sons: New York, 1991; pp 165-174.

(6) Allen, F. H. The Development, Status and Scientific Impact of Crystallographic Databases. Acta Crystallogr., Sect. A 1998, 54, 758771.

(7) Chapman, A. D. Principles and Methods of Data Cleaning - Primary Species and Species Occurrence Data; Global Biodiversity Information Facility: Copenhagen, 2005; p 2.

(8) Zhang, Y. M.; Evans, J. R. G.; Yang, S. Detection of Material Property Errors in Handbooks and Databases using Artificial Neural Networks with Hidden Correlations. Philos. Mag. 2010, 90, 4453-4474.

(9) Stark, J. G.; Wallace, H. G. Chemistry Data Book; John Murray: London, 1982 (1984 reprinted); pp 8-11, 50-51.

(10) Speight, J. G.; Lange, N. A.; Dean, J. A. Lange's Handbook of Chemistry, 16th ed.; McGraw-Hill: New York, 2005; pp 1.18-1.62, 1.124-1.127, 1.280-1.298.

(11) Emsley, J. The Elements, 3rd ed.; Clarendon Press: Oxford, 1998.

(12) Kaye, G. W. C.; Laby, T. H. Tables of Physical and Chemical Constants, 16th ed.; Longman: Harlow, 1995; pp 212-214, 338342.
(13) Lide, D. R. CRC Handbook of Chemistry and Physics, 81st ed.; CRC Press: Boca Raton, FL, 2000, pp (4) 124-125, (6) 105-108.

(14) Malinov, S.; Sha, W. Software Products for Modelling and Simulation in Materials Science. Comput. Mater. Sci. 2003, 28, 179-198.

(15) Zhang, Y. M.; Yang, S.; Evans, J. R. G. Revisiting Hume-Rothery's Rules with Artificial Neural Networks. Acta Mater. 2008, 56, 10941105.

(16) Gillies, D. How Should Research Be Organised?; College Publications: London, 2008; pp 35-39.

(17) Tabor, D. Gases, Liquids and Solids, 3rd ed.; Cambridge University Press: New York, 1991; pp 272-273.

(18) Hultgren, R.; Desal, P. D.; Hawkins, M.; Gleiser, M.; Kelley, K. K.; Wagman, D. D., Eds. Selected Values of the Thermodynamic Properties of the Elements; American Society for Metals: Metals Park, $\mathrm{OH}$, 1973.

(19) White, D.; Walsh, P. N.; Goldstein, H. W.; Dever, D. F. Rare Earths. II. A Mass Spectrometric Determination of the Heats of Sublimation (or Vaporization) of Neodymium, Praseodymium, Gadolinium, Terbium, Dysprosium, Holmium, Erbium and Lutetium. J. Phys. Chem. 1961, 65, 1404-1409.

(20) Trulson, O. C.; Hudson, D. E.; Spedding, F. H. Cohesive Energies of Europium, Gadolinium, Holmium, and Erbium. J. Chem. Phvs. 1961, $35,1018-1026$

(21) Wakefield, G. F.; Daane, A. H.; Spedding, F. H. Vapour Pressure of Holmium. J. Chem. Phvs. 1967, 47, 4994-4999.

(22) Lange, N. A.; Dean, J. A. Lange's Handbook of Chemistry, 12th ed.; McGraw-Hill: New York, 1979.

(23) Daane, A. H. Physical Properties of the Rare-Earth Metals. In The Rare Earths; Spedding, F. H., Daane, A. H., Eds.; John Wiley \& Sons, Inc.: New York, 1961; pp 177-189.

(24) Brooks, L. S. The Vapour Pressure of Tellurium and Selenium. J. Am. Chem. Soc. 1952, 74, 227-229.

(25) Bagnall, K. W. The Chemistry of Selenium, Tellurium and Polonium; Elsevier: New York, 1966; pp 37-38.

(26) Reid, R. C.; Prausnitz, J. M.; Poling, B. E. The Properties of Gases and Liquids, 4th ed.; McGraw-Hill: New York, 1987; p 219.

(27) De Podesta, M. Understanding the Properties of Matter, 2nd ed.; Taylor \& Francis: London, 2001; p 344.

(28) Habermann, C. E.; Daane, A. H. Vapour Pressures of the Rare-Earth Metals. J. Chem. Phvs. 1964, 41, 2818-2827.

(29) Spedding, F. H.; Barton, R. J.; Daane, A. H. The Vapour Pressure of Thulium Metal. J. Am. Chem. Soc. 1957, 79, 5160-5163.

(30) Arblaster, J. W. The Thermodynamic Properties of Platinum. Platinum Met. Rev. 2005, 49, 141-149.

(31) Arblaster, J. W. Vapour Pressure Equations for the Platinum Group Elements. Platinum Met. Rev. 2007, 51, 130-135.

Received for review October 26, 2010. Accepted December 15, 2010. The authors are grateful to the School of Engineering and Materials Science of Queen Mary, University of London, and the Central Research Fund from the University of London (ref.: AR/CRF/B), to support this work by providing a research studentship and research funds to Y.M.Z.

JE1011086 